\title{
RESPONSIVITAS PETANI TERHADAP AUDIT DI LEMBAGA KEUANGAN SYARIAH AUDITORS OF FARMERS'S RESPONSIVITY IN THE SHARIA FINANCIAL INSTITUTIONS
}

\author{
Fita Setiati ${ }^{1}$ \\ ${ }^{1}$ Pengajar Jurusan Akuntasi Politeknik Negeri Malang \\ fita_mulyadi@yahoo.com
}

\begin{abstract}
The purpose of this study was to determine the perception of farmers on the audit of Islamic financial institutions (LKS) in handling the financing of the needs of farmers in Sukopuro village, Jabung subdistrict, Malang regency. This research use desciptive qualitative approach. The population used in this study were the Sukopuro villagers who were members of the Joint Business Group (KUBE). Determination of the sample is done by purposive sampling with the criteria for the community that conducts business and utilizes funds from Islamic financial institutions in the area. The data collection techniques used are observation methods, interviews, documentation and focus discussion groups (FGD). Data analysis in the research in this study by recording data from the results of interviews, observation, documentation and FGD then organized to be sorted out to answer the problem formulation. This analysis is continued by finding and finding meaning related to the formulation of the problem.
\end{abstract}

Keywords : Responcivitas of farmers, shari'a of audit, islamic financial institutions (LKS)

\section{PENDAHULUAN}

Artikel ini merupakan hasil penelitian yang merupakan tindak lanjut dari penelitian tentang Persepsi petani di desa Sukopuro Kecamatan Jabung terhadap operasional Lembaga Keuangan Syariah (LKS). Masyarakat petani desa Sukopuro yang diwakili oleh anggota Kelompok Usaha Bersama (KUBE) menyatakan bahwa operasional LKS belum mengusung sepenuhnya nilai-nilai syariah. Hal ini terbukti lembaga tersebut belum bebas dari "Maghrib" (Maysir, Gharar, Haram, Riba, Batil) sebagai prinsip utama yang seharusnya melandasi segala gerak dan langkahnya. Disamping itu gerak yang tidak berlandaskan pada prinsip tersebut dinaungi oleh ketidakpahaman terhadap bentuk-bentuk akad (kontrak) di setiap transaksinya, sehingga lembaga keuangan syariah tersebut lemah profesionalitasnya. Dengan tidak terpenuhinya syariat dan implementasinya, maka LKS yang berinteraksi dengan petani yang tergabung dalam KUBE di desa Sukopuro dianggap suatu lembaga yang berlabelkan "Syariah" saja (Setiati, 2018).

Hasil penelitian diatas senada dengan Rahmanti (2013) yang menyatakan bahwa LKS hanyalah institusi konvensional yang menggunakan bahasa Arab untuk identifikasi produk dan transaksinya tanpa di dukung prinsip syariah dalam operasionalnya. Menurut Rahmanti hal ini terjadi dikarenakan sistem LKS merupakan adopsi dari lembaga keuangan konvensional.

Namun demikian, meskipun LKS mempunyai image yang kurang bagus dalam pengelolaannya, lembaga ini masih tetap eksis berdampingan dengan bank-bank Nasional, sedangkan LKS yang berbadan hukum Baitul Maal wat-Tamwil (BMT) sebagai lembaga keuangan syariah yang bersifat mikro semakin mengakar rumput di masyarakat. BMT sebagai lembaga yang lahir dengan tujuan untuk menggapai kalangan bawah berupa lembaga ekonomi rakyat kecil dalam upaya untuk mengembangkan usahausaha produktif dan investasi dalam meningkatkan kegiatan ekonomi pengusaha kecil berdasarkan prinsip syariah dalam bentuk koperasi. Lembaga inilah yang marak ada di desa Sukopuro dan melakukan interaksi dengan masyarakat petani di sana dalam memberikan pembiayaan untuk memenuhi kebutuhannya tidak berbelit-belit (Setiati, 2018).

Masih adanya respon positif dari masyarakat petani tentang keberadaaan LKS ini harus diiringi dengan peningkatan kredibilitas dalam wujud perbaikan pengawasan (audit) yang lemah (Mu'alim, 2003). Audit sebagai aktivitas vital dalam lembaga keuangan harus dilakukan secara langsung maupun tidak langsung sebagai wahana amar ma'ruf nahi munkar (Abidin, 2010). 


\section{METODE}

Penelitian ini menggunakan pendekatan deskriptif kualitatif. Populasi yang dipergunakan dalam penelitian ini adalah masyarakat desa Sukopuro yang tergabung dalam Kelompok Usaha Bersama (KUBE). Penentuan sampel dilakukan dengan purposive sampling dengan kriteria untuk masyarakat yang melakukan usaha dan memanfaatkan dana dari Lembaga keuangan Syariah di daerah tersebut. Adapun teknik pengumpulan data yang dipakai adalah metode observasi, wawancara, dokumentasi dan focus discussion group (FGD). Analisa data dalam penelitian ini dengan mencatat data dari hasil wawancara, observasi, dokumentasi dan FGD kemudian diorganisasikan untuk dipilah-pilah untuk menjawab rumusan masalah. Analisis ini dilanjut dengan mencari dan menemukan makna yang terkait dengan rumusan masalah.

\section{HASIL DAN PEMBAHASAN}

Pasar keuangan syariah yang lahir dengan konsep dan filosofi yang berbeda dengan pasar keuangan konvensional bersifat prinsipiil dan substansial. Prinsip syariah yang menjadi landasan dalam operasional lembaga keuangan syariah termasuk didalamnya sistem dan fungsi audit.

Filosofi dan konsep sistem dan fungsi audit dari suatu LKS dapat diwakili dari responsivitas petani dalam hal ini anggota KUBE yang sudah memanfaatkan jasa pembiayaan lembaga keuangan tersebut, adalah sebagai berikut:

\section{Kepatuhan Dewan Pengawas Syariah berbasis filosofi keuangan islam}

Kepatuhan merupakan manifestasi dari Seluruh prinsip syariah, yang diterapkan oleh Dewan Pengawas Syariah (DPS) dalam bentuk pengawasan terhadap akad, dari peluncuran produk sampai pada penggunaan produk LKS secara berkelanjutan.

Pengawasan atau audit yang akan dilakukan dalam suatu lembaga LKS harus berlandaskan pada kepatuhan syariah karena kepatuhan syariah. Budaya kepatuhan tersebut adalah nilai, perilaku dan tindakan yang mendukung terciptanya kepatuhan dari LKS terhadap ketentuan Bank Indonesia.
(Bank Indonesia, Peraturan Bank Indonesia Nomor 13/2/PBI/2011 Tentang Pelaksanaan Fungsi Kepatuhan Bank Umum, tanggal 12 Januari 2011). Di dalam aturan tersebut tertera prinsip syariah yang wajib dilaksanakan. Baik terkait dengan produk maupun kegiatan yang lain dalam perbankan syariah sebagaimana pendapat bapak MS sebagai salah satu anggota DPS menyatakan bahwa

"Yang terkait dengan kepatuhan syariah sebagai contoh: produknya, misalnya ya apakah ketika menyalurkan, menerima, dan jasa, iya kan begitu ya, jangan sampai ada penyaluran pembiayaan tidak sesuai syaria hanya aqad-aqad dinilai ya jangan sampai tidak sesuai aqad itu dengan produk itu, bisa menimbulkanmasalah. Akad yang berkaitan produk, bukan hanya memperhatikan akad yangsesuai dengan kepatuhan syariah tetapi mengawasi segala aktivitas yang berkaitandengan akad, baik dari peluncuran produksampai penggunaan produk secara berlanjut."

Hal ini merupakan penerapan prinsip syariah yang terdapat dalam kepatuhan syariah dari manifestasi filosofi keuangan islam yaitu bersifat insan. Ihsan atau selalu merasa diawasi oleh Allah swt dalam setiap aktivitasnya. DPS selain berkewajiban mengawasi juga melakukan pengarahan dan review atas semua aktifitas LKS agar sesuai dengan prinsip syariah islam (Agustianto ,2010: 1). Sebagaimana yang diungkapkan oleh Bapak MS (Anggota DPS):

"Sebetulnya memang subtansi dari
kepengawasan bagian di dalam
menasehati jangan sampai dia terjebak
keluar dari prinsip-prinsip AlQuran, prinsip-
prinsip apa yang disyaratkan di dalam fatwa
dewan syariah nasional."

Ungkapan anggota DPS ini diperkuat oleh nasabah sekaligus sebagai mitra bisnis LKS yaitu bapak BHR yang menyatakan:

"DPS perannya sebagai pengawas, maksudnya juga bersifat sebagai konsultan juga kan, konsultasi kan. Dia memberikan konsultasi, tempat konsultasi pihak LKS, dia juga sekaligus 
mengawasi

alur-alur

atau

persyaratan syariahnya.

DPS beraktivitas berdasarkan kepatuhan syariah yang fatwa-fatwanya diberikan dari DSN (Dewan syariah Nasiona), dimana kepatuhan syariah adalah syarat mutlak yang harus dipenuhi oleh lembaga keuangan yang menjalankan kegiatan usaha berdasarkan prinsip syariah. Secara tegas dinyatakan bahwa kepatuhan syariah adalah raison detre bagi institusi tersebut (Point 1 Islamic Financial Services Board).

\section{Fungsi audit syariah sudah sesuai dengan filosofi keuangan islam.}

Audit syariah merupakan lembaga independen yang bertugas membantu manajemen dalam melaksanakan tanggung jawabnya dengan memberikan analisis, penilaian, saran dan komentar mengenai kegiatan yang diperiksanya. Dalam melaksanakan tanggung jawab audit internal, sebuah standar praktik menjadi hal yang diperlukan agar auditor internal mampu menjaga kompetensi dan konsistensinnya dalam melakukan pekerjaan. Standar ini terdapat di dalam aturan BI. Hal ini sesuai dengan wawancara dengan Bapak Ilham (audit internal).

"Rujukan audit syariah dalam mengaudit perbankan adalah Al-quran dan Hadits, Peraturan Bank Indonesia, Peraturan Otoritas Jasa Keuangan, Fatwa Dewan Pengawas Syariah, Surat Keputusan Direksi, dan Surat Edaran Direksi."

Pelaksanaan audit bukan sekedar melaksanakan tetapi mengikuti aturan yang telah ditetapkan. Aturan yang paling penting adalah dari Al- Qur'an dan hadits. Ini menjadi pedoman utama dalam perbankan syariah. Karena aturan tersebut berasal dari Sang Pencipta. Bentuk tanggungjawab LKS kepada Sang Pencipta terlihat dari penerapan aturan syariah yang berdasar pada Al- Qur'an dan hadits. Audit syariah dapat dimaknai sebagai suatu proses untuk memastikan bahwa aktifitas-aktifitas yang dilakukan oleh institusi keuangan Islam tidak melanggar syariah atau pengujian kepatuhan syariah secara menyeluruh terhadap aktifitas bank syariah. Tujuan audit syariah adalah untuk memastikan kesesuaian seluruh operasional bank dengan prinsip dan aturan syariah yang digunakan sebagai pedoman bagi manajemen dalam mengoperasikan bank syariah (Minarni (2013: 33). Audit syariah memang berfungsi seperti yang disebutkan di atas, seperti yang diuangkapkan oleh Kepala Keuangan satu LK menyatakan:

\begin{abstract}
"Pemeriksaan sistematis atas kepatuhan seluruh aktivitas LKS terhadap prinsip syariah yang meliputi laporan keuangan, produk, penggunaan IT, proses operasi, pihak-pihak yang terlibat dalam aktivitas bisnis LKS, dokumentasi dan kontrak, kebijakan dan prosedur serta aktvitas lainnya yang memerlukan ketaatan terhadap prinsip syariah"
\end{abstract}

Keberadaan audit dalam LKS tidak lepas dari melakukan pemeriksaan atas seluruh kegiatan LKS (QS. Al Hujurat: 6) dengan tujuan tidak terdapatkecurangan atau pelanggaran aturan syariah di dalamnya. Hal ini menandakan bahwa aktifitas LKS di dasarkan pada aturan Sang Pencipta segalanya sebagaimana penempatan akuntabilitas tertinggi pada Tuhan menimpakan suatu musibah kepada suatu kaum tanpa mengetahui keadaannya yang menyebabkan kamu menyesal atas perbuatanmu itu". Ayat di atas memerintahkan untuk melakukan proses pemeriksaan sebelum mengambil sebuah keputusan. Wajib bagi LKS untuk melakukan hal ini agar LKS terhindar dari perilaku kecurangan.

Audit syariah jugamelaksanakan segala aktifitasnya berdasarkan pada sifat adil dan insan. Sifat insan bahwa seorang hamba pada saat melakukan aktivitas audit merasa bahwa dirinya selalu diawasi oleh Sang Pencipta, sehingga tidak memihak dengan kata lain berlakuadil adalah menegakkan yang haq dan berpegang pada kebenaran.Bersifat adil dan insan merupakan bagian dalam prinsip syariah atau aturan syariah, anatra audit syariah dan sifat adil dan insan yang merupakan filosofi keuangan islam sangat berkaitan. Hal tersebut sebagai aturan untuk menghindari perilaku kecurangan dalam operasional perusahaan.

Sedangkan Bank Negeri Malaysia mendefinisikan audit syariah adalah penilaian independen secara periodik dan penjaminan yang dirancang untuk memberikan nilai tambah dan menambahkan derajat kesesuaian pada operasi lembaga keuangan Islam, dengan tujuan memastikan sistem kontrol internet yang ada sesuai dengan asas syariah. Audit Syariah dilakukan oleh departemen independen yang 
menjadi bagian dari audit internal dalam melakukan pemeriksaan dan evaluasi pada suatu institusi dan melihat kesesuaiannya dengan aturan syariah, fatwa, dan ketentuan lainnya yang diterbitkan oleh IFI dan Syariah Supervisor Board (AAOIFI Governance Standard (GSIFI).

\section{Kepatuhan Dewan Pengawas Syariah sangat berkaitan dengan fungsi audit syariah}

Keterkaitan kepatuhan dewan pengawas syariah dan fungsi audit syariah adalah dewan pengawas syariah yang terikat dengan kepatuhan syariah wajib menjadikan prinsip syariah sebagai aturan dalam perbankan dalam mengawasi produk-produk LKS terutama pada produk baru dan mengawasi operasional LKS, audit syariah juga berperan penting karena audit syariah melakukan pemeriksaan sistematis atas seluruh aktifitas perbankan baik yang terkait dengan IT, operasional, dokumen, kebijakan dan prosedur. Disinilah fungsi audit syariah menjalankan tugasnya dengan yang memeriksa kepatuhan operasi-operasi keuangan syariah berdasarkan hukum syariah. Kepatuhan dewan pengawas syariah dan fungsi audit syariah tidak lepas dari filosofi keuangan Islam, yaitu bersikap adil dan memiliki sifat insan yang menghadirkan Sang pencipta di setiap aktifitasnya. Merasa selalu diawasi oleh Sang Pencipta sehingga aktifitasnya akan terhindar dari kecurangan. Dewan pengawas syariah dan audit syariah menghadirkan hal tersebut sebagaimana ungkapan dari Bapak ILH (auditor syariah).

"Berhubungan, karena audit hadir untuk memastikan tidak bertentangan dengan aturan syariah"

Ditambahkan oleh Bapak MS (anggota DPS)

"Islam dibangun landasannya ya tentu berdasar pada ketauhidan ya, kalau Umar Capra bilang itu harus diawali dari tauhid dan disitulah eksistensi manusia sebagai hamba Allah yang harus menjalankan amanah ya, menjalankan tugasnya ya dia Islam tapi dia tunduk pada syariat Islam secara kaffah, iya kan, bayar zakat, iya kan, begitu. Yang kedua adalah filosofi ekonomi, filosofi keuangan Islam itu, orang yang menjalankan amanah muamalah ndak boleh berdimensi riba kan, ini ndk boleh"

LKS yang mengemban metafora amanah dan metafora zakat maka lembaga tersebut harus menjalankan segala aktifitasnya dengan aturan syariah. Karena LKS merupakan wadah bagi umat muslim dalam melaksanakan segala aktivitasnya aktifitasnya tanpa menggunakan riba sehingga lembaganya akan mendapat kepercayaan dari nasabah pada umumnya dan umat muslim pada khususnya

\section{KESIMPULAN}

1. Responsivitas petani desa Sukopuro Kecamatan Jabung terhadap audit di Lembaga Keuangan Syariah (LKS) diharapkan dilakukan sesuai dengan filosofi keuangan Islam yang berprinsip pada konsep adil dan insan dalam perspektif Al Quran dan Hadits (Arman, 2013).

2. Kedua konsep dari filosofi keuangan Islam diharapkan dipatuhi oleh Dewan Pengawas Syariah sebagai kontrol terhadap fungsi audit syariah dalam pelaksaanaannya.

3. Sustainability dari responsibility audit suatu LKS sangat dipengaruhi oleh keterkaitan kepatuhan dewan pengawas syariah dengan fungsi audit. Kedua elemen tersebut berkaitan dalam hal pengawasan terhadap operasional dan manajemen dari LKS.

\section{DAFTAR PUSTAKA}

AAOIFI. (2005). Governance Standards for IFIs, No. 1-5, Bahrain, AAOIFI.

Kementrian Urusan Agama Islam, Wakaf, Dakwah Dan Bimbingan Islam Kerajaan Arab Saudi, Yang Menaungi Mujamma' Al Malik Fahd Li Thiba'at Al Mush-Haf Asy Syarif. (1990) Al Qur'an dan Terjemahannya,KompleksPercetakanAlqu r'anRajaFahd).

Abidin. (2011) Pengawasan Perbankan Syariah (Studi Pemikiran Muhammad Syafi'i Antonio), Maliyah,1(1),

Accounting and Auditing Organization for Islamic Financial Institution.(1999) Accounting and Auditing and Governance Standard for 
Islamic Financial Institutions. Manama Bahrain: AAOIFI.

Arman, Saleh Md. (2013). Shariah Compliance Features of Islamic Financial Institutions and Its Challenges, Arabian Journal of Bussiness and Management Review (OMAN Chapter), 3 (4), 91-98

Bank Indonesia. (2011) Pelaksanaan Fungsi Kepatuhan Bank Umum, Peraturan Bank IndonesiaNomor13/2/PBI/2011.

Mu'allim, Amir. (2003). "Persepsi Masyarakat Terhadap Lembaga Keuangan Syariah", Al Mawarid Journal of Islamic Law, Vol 10

Rahmanti, Virginia Nur. (2013) Mengapa Perbankan Syariah Masih Disamakan Dengan Perbankan Konvensional?, Jurnal Manajemen dan Akuntansi Islam IMANENSI,1(1),1-74.

Setiati, Fita. (2018) Persepsi Petani tentang Lembaga Keuangan Syariah yang Menengani Pembiayaan Kebutuhan Petani di desa Sukopuro Kecamatan Jabung Malang, Jurnal Agriment, Vol 2, No 2, Juni. 